DIAJAR: Jurnal Pendidikan dan Pembelajaran
https://journal.yp3a.org/index.php/DIAJAR
ISSN Media Elektronik xxxx-xxxx
Vol. 1 No. 1 (Januari 2022) 72-79
DOI: xxxxx

\title{
Pelaksanaan Manajemen Kurikulum Pesantren Dalam Membentuk Karakter Mandiri Santri
}

\begin{tabular}{|c|c|}
\hline \multicolumn{2}{|c|}{$\begin{array}{c}\text { Muhammad Yasin } \\
\text { Pendidikan Agama Islam, Tarbiyah, STAI Sangatta, Indonesia } \\
\text { Email: mysgt1978@gmail.com }\end{array}$} \\
\hline Informasi Artikel & Abstract \\
\hline $\begin{array}{r}\text { Diterima }: 12-12-2021 \\
\text { Revisi }: 16-12-2021 \\
\text { Diterbitkan }: 20-12-2022 \\
\text { Keywords: } \\
\text { Management } \\
\text { Pesantren Curriculum } \\
\text { Independent Character }\end{array}$ & $\begin{array}{l}\text { Forming the independent character of students is not an easy job, } \\
\text { where students who are accustomed to being in the cradle of their } \\
\text { parents will tend to be spoiled and lazy when they have to face } \\
\text { different realities in pesantren life, so good curriculum } \\
\text { management is needed to grow their independent character. This } \\
\text { study aims to analyze the implementation of Islamic boarding } \\
\text { school curriculum management, and efforts to form the } \\
\text { independent character of students in the Daarus Sholah Islamic } \\
\text { boarding school, Kampung Kajang, South Sangatta. This research } \\
\text { applies qualitative research with descriptive research type, where } \\
\text { the data obtained is data collected in the form of descriptions, and } \\
\text { illustrations. The result is that pesantren curriculum management } \\
\text { cannot be separated from the management function known as } \\
\text { POAC, namely planning, organizing, actuating, controlling, where } \\
\text { the four functions were popularized with the terms planning, } \\
\text { organizing, implementing, and evaluating. These four functions } \\
\text { have been carried out at the Darus Sholah Very South Islamic } \\
\text { boarding school. Furthermore, in an effort to form the } \\
\text { independent character of students at the Daarus Sholah Islamic } \\
\text { Boarding School, it is carried out with fish farming and } \\
\text { agriculture programs as well as habituation of students in } \\
\text { carrying out all their own activities of course accompanied by } \\
\text { strict supervision from the boarding school caregivers. The } \\
\text { implication is that this independent character is expected to be a } \\
\text { provision for the students when the students are no longer in the } \\
\text { boarding school environment and are no longer in the family } \\
\text { environmentwhen they are adults. }\end{array}$ \\
\hline
\end{tabular}

\begin{abstract}
Abstrak
Membentuk karakter mandiri santri bukanlah merupakan pekerjaan yang mudah, dimana para santri yang sudah terbiasa dalam buaian orang tua akan cenderung manja dan bermalas-malasan ketika harus menghadapi kenyataan yang berbeda dalam kehidupan pesantren, sehingga diperlukan manajemen kurikulum yang baik untuk menumbuhkan karakter kemandiriannya. Penelitian ini bertujuan untuk menganalisis pelaksanaan manajemen kurikulum pondok pesantren, dan upaya membentuk karakter mandiri santri di pondok pesantren Daarus Sholah Kampung Kajang Sangatta Selatan. Penelitian ini menerapkan penelitian kualitatif dengan jenis penelitian deskriptif, dimana data yang didapatkan merupakan data yang dikumpul dalam bentuk deskripsi, dan ilustrasi. Hasilnya adalah manajemen kurikulum pesantren tentu tidak lepas dari fungsi manajemen yang dikenal dengan istilah POAC yaitu planning, organizing, actuating, controlling, dimana keempat fungsi tersebut dipopulerkan dengan istilah perencanaan, pengorganisasian, pelaksanaan, dan evaluasi. Keempat fungsi tersebut telah terlaksana di pondok pesantren Darus Sholah Sangatta Selatan. Selanjutnya dalam upaya membentuk karakter mandiri santri di Pondok Pesantren Daarus Sholah dilakukan dengan program program peternakan ikan dan pertanian serta pembiasaan santri dalam melakukan segala aktivitasnya sendiri tentunya dibarengi dengan pengawasan yang ketat dari pengasuh pondok pesantren. Implikasinya adalah diharapkan karakter mandiri ini menjadi bekal para santri ketika santri sudah tidak berada di lingkungan pondok pesantren dan tidak lagi berada di lingkungan keluarga ketika mereka telah dewasa.
\end{abstract}

Kata Kunci: manajemen, kurikulum pesantren, karakter mandiri. 


\section{PENDAHULUAN}

Idealnya manajemen kurikulum merupakan sistem dengan pengelolaan yang komprehensif, kooperatif, sistematis dan sistemik untuk mencapai tujuan dari pada kurikulum itu sendiri[1]. Kemajuan sebuah lembaga Pesantren tidak lepas dari bagaimana penerapan manajemen kurikulum, manajemen kurikulum yang ideal memiliki peran yang sangat penting dalam mempersiapkan kegiatan pembelajaran di setiap lembaga pendidikan. Kurikulum mengandung penjabaran nilai-nilai untuk dapat sampai pada tujuan pembelajaran serta karakteristik mata pelajaran[2]. Kurikulum ideal, yaitu kurikulum yang berisi panduan yang ideal, sesuatu yang dicita-citakan sebagaimana yang tertuang pada dokumen kurikulum Pondok pesantren[3]. Karena pondok pesantren sangat berperan sebagai basis pendidikan Islam sebab sangat dibutuhkan dalam kehidupan dan berbangsa[4].

Faktanya manajemen kurikulum hari ini masih jauh dari kata ideal. Manajemen kurikulum yang dijumpai di berbagai lembaga pendidikan masih menerapkan manajemen "dadakan", atau manajemen "kebiasaan". Apalagi jika dikaitkan dengan karakter yang notaben menjadi isu baru dalam pengembangan kurikulum. Salah satu problem dalam manajemen kurikulum pada pendidikan karakter sebagaimana hasil penelitian Siti Julaiha bahwa problem kurikulum dan pembelajaran pendidikan karakter, yaitu perumusan kurikulum pendidikan karakter masih di bawah kepentingan politik kelompok. Kurikulum pendidikan karakter juga tumpang tindih dengan kurikulum pendidikan kewarganegaraan, pendidikan Pancasila, dan pendidikan agama.[5]

Penelitian yang relevan berkaitan dengan manajemen kurikulum pondok pesantren pernah dilakukan oleh Nurul Huda dari artikelnya membahas tentang Pengembangan manajemen kurikulum yang dielaborasikan dengan pendidikan Islam. Hasilnya adalah pengembangan manajemen kurikulum dilakukan dengan cara lebih menekankan pada aspek sistematis, aspek universal dan holistic[6] Penelitian selanjutnya dilakukan oleh Yuhasnil dalam artikelnya manajemen kurikulum ditemukan kearah peningkatan lebih mutu ke penjabaran atau implementasinya manajemen kurikulum mengacu pada tuntunan manajemen kurikulum pusat[7], senada dengan Nur Ahmad dalam Artikelnya manajemen kurikulum lebih pada Perencanaan mempersiapkan berbagai hal yang mendapat menunjang keberhasilan, pelaksanaan berjalan berdasarkan sesuai perencanaan, dan evaluasi terlaksana menyesuaikan dengan perencanaan dan pelaksanaan sesuai dengan kurikulum kepesantrenan.[8]. Pada skripsi Akhmad Malikul Ngilmi penanaman nilai karakter itu melalui aktivitas ekstrakurikulerpramuka.[9] Sedangkan penelitian yang akan dilakukan penulis mengungkapkan mengenai penanaman karakter yang terdapat dalam diri seseorang santri melalui aktivitas sehari-hari pada pondok pesantren. Adapun persamaan antara penelitian ini menggunakan penelitian yang telah terdapat misalnya milik, rohma adalah sama-sama meneliti mengenai pendidikan karakter pada sebuah lembaga pendidikan[10].

Berkaitan dengan fakta dan teori yang dipaparkan di atas tentang manajemen kurikulum pesantren yang telah diterapkan di salah satu lembaga di Pondok Pesantren Daarus Sholah Kampung Kajang Sangatta Selatan. Oleh karena itu, peneliti ingin mengetahui terhadap manajemen kurikulum pesantren dalam membentuk karakter santri. Berangkat dari deskripsi tersebut, maka peneliti tertarik untuk mengadakan penelitian dengan judul Manajemen Kurikulum Pesantren dalam membentuk karakter santri di Pondok Pesantren Daarus Sholah kampung Kajang Sangatta Selatan Kabupaten Kutai Timur. Penelitian ini berfokus pada bagaimana manajemen kurikulum pondok pesantren, dan bagaimana membentuk karakter santri di pondok pesantren Daarus Sholah Kampung Kajang Sangatta Selatan.

\section{METODE PENELITIAN}

Penelitian ini menerapkan pendekatan kualitatif dengan jenis deskriptif, dimana data yang didapatkan merupakan data yang dikumpul dalam bentuk deskripsi, ilustrasi dan bukan merupakan data yang berbentuk angka-angka. Isi laporan dalam jenis deskriptif kualitatif berupa data kutipan dengan deskripsi penulis dalam menyampaikan laporan. Data-data penelitian yang didapatkan dari wawancara, observasi lapangan dan dokumentasi kemudian dicatat dan dideskripsikan[11, p. 11]. Jadi penelitian ini berusaha menganalisis data menggunakan pendekatan kualitatif dengan harapan penulis bisa lebih dekat dengan subjek penelitian. Dengan demikian akan lebih mudah mendapatkan data penelitian, dan berinteraksi dengan subjek penelitian, serta memudahkan penulis dalam mendeskripsikan data penelitian.

Penulis mencoba mengkaji tentang pelaksanaan manajemen kurikulum pesantren dalam membentuk karakter mandiri santri pondok pesantren Daarus Sholah. Penulis mengambil data dengan cara melakukan observasi dalam bentuk kunjungan dan sowan kepada pembina pesantren. Pada saat yang bersamaan penulis melakukan wawancara, dan melakukan dokumentasi di lokasi penelitian[12, p. 60]. Observasi yang digunakan penulis yaitu observasi non partisipan dimana posisi penulis menjadi pengamat semata. Peneliti sendiri bukan sebagai pengurus yayasan atau sebagai guru di pondok pesantren tersebut sehingga seobjektif mungkin dalam membuat catatan lapangan. Demikian juga dengan wawancara, 
peneliti menggunakan wawancara tidak terstruktur sehingga bisa mendapatkan keterangan yang lebih mendalam.

\section{HASIL DAN PEMBAHASAN}

\subsection{Manajemen Kurikulum Pesantren dalam Membentuk Karakter Santri}

Manajemen dan kurikulum merupakan satu kesatuan yang tidak bisa dipisahkan, dimana dalam kurikulum tentu ada manajemen sebagai alat untuk melaksanakan kurikulum yang ada. Perkembangan kurikulum dari waktu ke waktu memang menjadi isu yang terus bergulir. Kurikulum yang berubah-ubah menjadikan proses implementasinya di lembaga pendidikan pesantren terkadang menjadi kendala yang berkepanjangan. Ketika membicarakan manajemen kurikulum pesantren tentu tidak lepas dari fungsifungsi manajemen[13] yang dikenal dengan istilah POAC yaitu planning, organizing, actuating, controling[14]. Dimana keempat fungsi tersebut dikenal dengan istilah perencanaan, pengorganisasian, pelaksanaan, dan evaluasi[15]. Pelaksanaan manajemen kurikulum pada prosesnya tentu membutuhkan sebuah perencanaan sebagaimana fungsi pertama dari manajemen itu sendiri. Demikian juga dalam fungsi pengorganisasian, pelaksanaan dan evaluasinya.

Berkaitan dengan Manajemen Kurikulum Manajemen Pesantren menurut Fathurrochman dan Irwan manajemen adalah : a). Efisiensi Sumber daya Kurikulum, b) memberikan kesempatan peserta didik untuk mencapai maksimal, c). memaksimalkan pembelajaran peserta didik efektif dan efesien, 4) efektivitas kinerja guru maupun aktivitas siswa dalam pembelajaran; e). efektivitas dan efisiensi dalam proses belajar mengajar; f). partisipasi masyarakat[16], demikian juga pendapat dari Indana Dkk yaitu a). merencanakan materi dan waktu pengajaran yang melalui musyawarah dengan Pembina, Stakeholder serta seluruh ustadz/Ustadzahnya, b). pelaksanaan pembelajaran sesuai petunjuk lembaga, c). Evaluasi pembelajaran tentang hasil dan faktor pendukung dan penghambatnya[17], begitu juga pendapat[18] manajemen kurikulum itu menunjukkan bahwa berkembang secara variatif baik dari isi (kurikulum) maupun bentuk (manajemen) serta struktur organisasinya. Sejalan dengan penyelenggaraan pendidikan formal, beberapa pesantren mengalami perkembangan pada aspek pembentukan karakter mandiri santri.

Lembaga Ponpes Daarus Sholah kampung kajang didirikan oleh Kyai Sudarsono dan Para Tokoh Masyarakat kampung Kajang Sangatta Selatan berdirinya pada tahun 2007, para Pembina Bapak Imam Syafi'i, Bapak M Tholib, ketua yayasan Ustadz M. Sulhan Abidin, Pengasuh ibu nyai hj Malihah dan Ustadz Khabib Maslukhi, Ponpes ini merupakan lembaga yang independen dan tidak berafiliasi atau terkontaminasi ke partai politik maupun organisasi lainnya, karena paradigma ponpes lebih ke pendidikan dan pengajaran agar lebih komunikatif, lebih efektif dalam mendidik, membimbing para santri oleh Pembina selama berasrama.

Dalam bukunya Ghozali sistem Pesantren Madrasah Kata "pesantren” berasal dari bahasa sansekerta yang terdiri dari dua kata yaitu "Sa" dan "Tra". "Sa" yang berarti orang yang berperilaku yang baik, dan "tra" berarti suka menolong,[19] disisi lain kata pesantren berasal dari kata dasar "santri" yang mendapat awalan pe dan akhiran an yang berarti tempat tinggal para santri. Mengutip dari dari wahjoetimo pesantren sebuah kompleks yang mana umumnya terpisah dari kehidupan sekitarnya, dalam kompleks itu berdiri beberapa bangunan rumah kediaman pengasuh. Dapat pula dikatakan pesantren adalah kata santri yaitu seseorang yang belajar agama Islam melalui tempat tertentu.[20] Pengembangan yang mendesak untuk dilakukan pada pesantren merupakan pembaharuan yang bersifat horizontal, pembaharuan ini mencakup sistem pendidikan dan manajemen pesantren,[21] pembaharuan sistem pendidikan ini mencakup: jenis, jenjang, dan asal daya pendidikan. Pembaharuan jenis pendidikan merupakan menggunakan memasukkan jenis pendidikan lain disamping pendidikan kepercayaan misalnya pendidikan akademik atau pendidikan kejuruan (keterampilan). Jenis pendidikan akademik[22]

\section{Perencanaan dalam manajemen kurikulum Pesantren}

Perencanaan dalam kurikulum pesantren sejujurnya mempunyai tujuan untuk membuat sebuah prediksi-prediksi yang akurat demi kemajuan pesantren dan demi terbentuknya kemandirian santri. Perencanaan mempunyai peran penting dan sangat krusial dalam manajemen kurikulum karena dalam perencanaan ada asa dan harapan yang diletakkan jauh di depan sehingga mampu membuat keputusankeputusan yang dapat mendukung tercapainya tujuan pendidikan karakter mandiri santri. Guru dalam hal ini Ustadz atau pembina pondok pesantren sebagai seorang manajer di pondok pesantren Daarus Sholah harus mampu mengelola kurikulum dan iklim pesantren sebagai lingkungan belajar yang representatif [23].

Sebagaimana yang terjadi di Pondok Pesantren Daarus Sholah kampung kajang Kecamatan Sangatta Selatan, yang saat ini mengalami tantangan arus globalisasi dan modernisasi yang menyebabkan desakan untuk beradaptasi dengan tantangan yang ada. Hasil adaptasi pesantren diantaranya ada yang 
mengubah menjadi pesantren modern yang diikuti oleh perubahan manajemen kurikulum, Perlunya manajemen kurikulum di Ponpes Daarus Sholah Kampung Kajang Sangatta karena suatu kebutuhan agar bisa bersaing diera globalisasi, juga bisa sebagai landasan Ponpes dimasa yang akan datang sehingga Pondok Pesantren berjalan secara efektif dan sesuai dengan visi, misi dan tujuan yang telah ditetapkan oleh Pondok Pesantren Daarus Sholah Kampung Kajang Kecamatan Sangatta Selatan Kabupaten Kutai Timur. Awal mula berdirinya ponpes ini juga karena adanya inisiatif dari tokoh dan masyarakat setempat dimana lingkungan disini bisa dibilang lingkungan yang luar biasa karena adanya lingkungan lokalisasi yang sudah resmi ditutup maka itu memang sangat dibutuhkan sebuah lembaga yang menjadi solusi permasalahan-permasalahan seorang anak terutama dari segi akhlaknya. Faktor pendukungnya ada buku panduan dari kementerian Agama, dana, kesemangatan antara santri dan guru Faktor penghambatnya ada beberapa guru yang belum paham atau belum mengerti tentang kurikulum itu sendiri sehingga waktu pelaksanaan kurang maksimal, fasilitas tempat yang masih sangat terbatas.

Ibu Munfiatik mengungkapkan saat wawancara berlangsung bahwasanya dalam perencanaan kita punya jadwal harian, mingguan bulanan dan juga tahunan. pelaksanaan jadwal harian anak-anak bangun pagi shalat subuh setelah itu tahfidzul qur'an juz 30, piket bersih2, mandi, sarapan pagi, berangkat ke sekolah waktu belum ada pandemic, shalat dzhuhur, istirahat, shalat Ashar, mengaji tpa, pembacaan waqiah menjelang maghrib, shalat maghrib, sekolah diniyah, shalat Isya, makan malam, pendampingan belajar, tidur malam, untuk shalat malam kami belum bisa menerapkan karena pernah kita coba melaksanakan namun ketika belajar di sekolah SD ada beberapa guru menyampaikan kalau anak-anak pesantren sering ngantuk di sekolahannya maka kami putuskan untuk tidak dulu menerapkan shalat malam untuk pelaksanaan jadwal mingguan setiap malam jum'at pembacaan surat yasin dan tahlil, setiap malam sabtu diisi dg latihan habsyi, malam minggu les bahasa inggris /bahasa arab, minggu pagi habis subuh istighosah dzikru syafa'at, dan sekitar jam 7 minggu pagi santri-santri diajak senam Pelaksanaan jadwal bulanan setiap bulan kami mengadakan khotmil qur'an berkolaborasi dg masyarakat sekitar Pelaksanaan kegiatan tahunan pembacaan do'a awal tahun akhir tahun bersama, perayaan maulid nabi, perayaan hari santri Dalam evaluasinya depo air yang sudah kita beli 1 tahun belakangang paling tidak kita bisa mengirit pengeluaran uang air sekaligus bisa menjadikan ini sebagai usaha mandiri bagi pesantren kami

Tujuan manajemen kurikulum pesantren untuk membentuk karakter mandiri santri dapat terwujud dengan perencanaan yang matang. Pendidikan berkarakter santri melalui manajemen kurikulum pesantren yang memadai menggunakan prinsip keterpaduan moral knowing, moral feeling dan moral action melalui pendekatan keteladanan dan pendekatan sistem[24] Pendidikan karakter santri di Pesantren menumbuhkan kembangkan nilai-nilai karakter religius, ikhlas, mandiri, penuh perjuangan, peduli, tanggung jawab, nasionalis dan mengutamakan kepentingan umat, pembentukan karakter ini terbentuk di pondok pesantren Daarus Sholah kampung kajang Sangatta Selatan dan salah satu yang menjadi konsen penulis yaitu karakter mandiri santri.

\section{Pelaksanaan dalam manajemen kurikulum Pesantren}

Pelaksanaan kurikulum merupakan bentuk fungsi ketiga dari fungsi-fungsi manajemen, dimana setelah adanya perencanaan yang matang kemudian diorganisasikan sesuai dengan skala prioritas dalam pelaksanaan manajemen kurikulumnya. Setelah mengorganisasikan kurikulum yang ada maka dihasilkan perencanaan-perencanaan tersebut diklasifikasikan pada perencanaan jangka pendek, perencanaan jangka menengah, dan perencanaan jangka panjang. Tentu disetiap rencana yang ada terdapat perencanaan yang menjadi skala prioritas. Pada prosesnya pelaksanaan kurikulum merupakan rangkaian proses dalam pembelajaran di lembaga pendidikan yang dapat memberikan kepastian terlaksananya proses pembelajaran dengan pendayagunaan tenaga pendidik yang ada di lembaga pendidikan. Dalam pelaksanaannya, kurikulum dapat diterapkan apabila didukung dengan sumber daya yang profesional serta sarana dan prasarana yang memadai[25].

Fungsi pelaksanaan dalam manajemen kurikulum pesantren dapat dilaksanakan dengan baik juga pemimpin menjalankan manajemen dengan baik. Apabila kurikulum telah dijalankan dengan baik maka akan menghasilkan output yang baik pula sehingga akan menjadi branding tersendiri bagi lembaga pendidikan. Semakin baik pelaksanaan manajemen kurikulum pesantren dan dilaksanakan berdasarkan perencanaan yang telah disusun maka akan semakin baik pula hasil yang akan diperoleh, sehingga diharapkan dapat meningkatkan animo masyarakat untuk menyekolahkan anaknya di pondok pesantren. Manajemen kurikulum merupakan menjadi suatu sistem pengelolaan kurikulum yang kooperatif, komprehensif, sistemik, dan sistematis pada rangka mewujudkan ketercapaian tujuan kurikulum[26] Dari sini jelas, bahwa manajemen kurikulum bisa dikatakan suatu aktivitas yang terjadwal \& sistematis yang mengikat pihak-pihak yang berkepentingan pada global pendidikan demi mencapai sasaran pendidikan yang sudah ditetapkan sebelumnya[27] 
Pondok Pesantren Darus Sholah Kampung kajang Sangatta Selatan Kabupaten Kutai Timur adalah pondok pesantren Putra Putri yang memadukan model pesantren terkini dengan model klasik, yakni model pesantren salafi, namun banyak juga diwarnai corak khalaf. Pondok Pesantren Darus Sholah Kampung kajang Sangatta Selatan Kabupaten Kutai Timur ini, terdapat dua macam kurikulum madrasah, yaitu Madrasah Madrasah Diniyah dan Sekolah umum, dimana proses pembelajaran terjadi mulai sebelum shalat subuh, Ba'da Ashar, dan mulai selepas maghrib sampai pukul 22.00 WIB malam. Selain itu pada pagi sekolah umum, ada yang sekolah di Sekolah Dasar dan Sekolah Menengah Pertama. Manajemen Kurikulum santri aktivitasnya sesuai dengan jadwal kegiatan pondok mulai sebelum subuh sampai pukul 22.00 berjalan dengan baik, ini juga sejalan dengan pendapat majir bahwa manajemen kurikulum santri bisa dikatakan suatu aktivitas yang terjadwal \& sistematis yang mengikat pihak-pihak yang berkepentingan pada global pendidikan demi mencapai sasaran pendidikan yang sudah ditetapkan sebelumnya[27]

Dalam manajemen kurikulum aktivitas dititik beratkan dalam usaha pelatihan situasi belajar di pesantren supaya selalu terjamin kelancarannya. Kegiatan manajemen kurikulum antara lain: 1). Perencanaan kurikulum merupakan menjadi suatu proses sosial yang kompleks, yang menuntut aneka macam jenis dan taraf perbuatan keputusan menggunakan mempertimbangkan kebutuhan warga melalui contoh perencanaan yang tepat. Pengajar yang baik akan berusaha sedapat mungkin supaya pengajarannya berhasil. 2). pelaksanaan program manajemen kurikulum yang telah dikembangkan dalam tahap sebelumnya, kemudian diujicobakan dengan pelaksanaan dan pengelolaan, sambil senantiasa dilakukan penyesuaian terhadap situasi lapangan dan karakteristik peserta didik, baik pengembangan intelektual, emosional, serta fisiknya. 3) Evaluasi kurikulum suatu proses pengumpulan data secara sistematis, yang bertujuan untuk membantu pengajar memahami dan menilai kurikulum, serta memperbaiki metode pembelajaran.[28] Terdapat lima prinsip yang harus diperhatikan dalam melaksanakan manajemen kurikulum,yaitu:a). Produktivitas, b). Demokratisasi, c).Kooperatif, d). Efektifitas dan Efisiensi, e) mengarahkan visi, misi dan tujuan.[29]

\subsection{Membentuk Karakter Mandiri Santri Pondok Pesantren Darus Sholah}

Membentuk karakter mandiri kepada para santri bukanlah merupakan pekerjaan yang mudah, dimana para santri yang sudah terbiasa dalam buaian orang tua akan cenderung manja dan bermalasmalasan ketika harus menghadapi kenyataan yang berbeda di pondok pesantren. Salah satu karakter yang harus dimiliki oleh seorang santri adalah karakter mandiri. Karakter mandiri merupakan suatu bentuk sikap dan perilaku seseorang dalam melakukan berbagai macam aktivitas sendiri tanpa mengharapkanorang lain [30]. Menurut mustari sebagaimana dikutip Nova et. al, mandiri merupakan sikap dan perilaku yang tidak mudah menaruh harapan dan bergantung kepada orang lain dalam menyelesaikan berbagai macam aktivitas dalam kehidupan nyata [31].

Manajemen dalam membentuk karakter mandiri santri merupakan bentuk proses perencanaan, pengorganisasian, pengawasan, dan penilaian sebagai bentuk usaha dalam proses pendidikan untuk mencapai tujuan yang telah direncanakan pada suatu lembaga pendidikan [32]. Sedangkan karakter merupakan modal individual yang terpatri di dalam diri seseorang yang berkaitan dengan nilai-nilai yang ada dalam diri mereka seperti nilai kebaikan, nilai kemandirian, nilai religiusitas, dan nilai nasionalisme yang akan berefek pada lingkungan dengan tingkah laku yang dilakukannya. Karakter seseorang akan terlihat dari bagaimana ia bertingkah laku di tengah kehidupan sosial, agama, maupun negara. Karakter seseorang juga akan terlihat dalam akhlak, kemampuan, pola pikir, dan sikap dalam menyelesaikan problem yang dihadapinya. Faktanya dalam Proses pendidikan di ponpes Daarus Sholah dilaksanakan manajemen kurikulum supaya perencanaan, aplikasi \& penilaian kurikulum berjalan efektif, efisien, \& optimal pada memberdayakan banyak sekali asal belajar, pengalaman belajar, juga komponen kurikulum. Hal tersebut tentunya sesuai dengan apa yang ditulisan Aisyah tentang penanaman nilai karakter yang dilakukan itu melalui pendekatan pendidikan kepercayaan Islam[33].

Karakter mandiri seorang santri tentu merupakan sebuah kewajiban mengingat seorang santri ketika telah masuk ke dalam pesantren akan berpisah sementara dari orang tuanya, sehingga mau tidak mau santri harus belajar menjadi seseorang yang mandiri[34]. Dari keterpaksaan tersebut kemudian karakter santri tersebut bisa dibentuk dengan usaha dan kegigihan pengasuh pondok pesantren yang mengkolaborasikan antara religiusitas dengan kemandirian. Kemandirian seorang santri dikolaborasikan dengan karakter religius berupa pembiasaan bangun pagi sebelum shalat subuh supaya dapat melaksanakan shalat tahajjud. Sebagaimana hasil wawancara dengan Ustadz Khabib bahwasannya pendidikan dan Pengajaran Santri berkarakter itu teladan para ustadz dan ustadznya dan santri akan mengikuti ustadznya, para ustadz juga mengajarkan tentang etika bagaimana dengan seorang santri ketemu gurunya harus bersalaman, membiasakan bangun sebelum subuh sholat Tahajjud berjamaah, kemudian mengaji al-quran sebelum subuh, Mereka pula dididik buat shalat jama'ah beserta oleh kiainya yang sebagai imam menjadi wujud membimbing tanggung jawab \& kebersamaan. Santri pula dididik Lisensi: Creative Commons Attribution 4.0 International (CC BY 4.0) 
menaati peraturan pada pesantren menjadi bentuk disiplin dan pencerahan hayati beserta, hayati berkomunitas menggunakan kecenderungan hak \& kewajiban.

Diantara upaya yang dapat dilakukan dalam membentuk karakter mandiri santri yaitu dengan mengajarkan santri untuk memasak sendiri, mengajari santri membersihkan dan merapikan kembali tempat tidurnya, mengajari santri untuk meletakkan kembali barang sesuai tempat semula, mendisiplinkan santri melakukan berbagai persiapan secara mandiri sebelum jadwal pembelajaran di kelas, dan memberikan keteladanan, serta contoh yang baik dalam upaya menanamkan kemandirian santri [35]. Selain itu dalam membentuk kemandirian santri, pondok pesantren Daarus Sholah juga mempunyai program pertanian dan program peternakan.

Program Peternakan yang dilaksanakan di pondok pesantren Daarus Sholah merupakan usaha konkrit dalam upaya menumbuhkan karakter mandiri santri sebagai bekal hidup setelah menyelesaikan studi di pondok pesantren. Salah satu bentuk peternakannya adalah budidaya ikan. Tujuannya jelas untuk melatih dan membiasakan santri untuk budidaya ikan dengan memanfaatkan kolam yang ada di sekitar pondok pesantren. Dengan demikian nantinya santri sudah terlatih untuk mandiri dengan bekerja dengan gigi dan dapat menghasilkan an bahkan sampai pada membuka lapangan pekerjaan dengan keterampilan mandiri yang dia miliki.

Selain program peternakan dalam bentuk budidaya ikan, kemandirian santri juga diupayakan melalui pertanian. Mengingat lokasi pesantren yang jauh dari pusat kota dan dikelilingi oleh lahan pertanian sehingga sangat tepat jika upaya membentuk karakter mandiri seorang santri dilakukan dengan program pertanian. Program pertanian dengan bercocok tanam sayur mayur dan kebutuhan pokok lain selain dapat melatih kemandirian santri juga dapat menghemat dari segi ekonomi karena kebutuhan pokok didapatkan dari hasil pertanian yang dilakukan oleh pihak pondok pesantren. Dalam pelaksanaannya mungkin belum maksimal mengingat santri masih belum terbiasa, dan belum mahir dalam hal bercocok tanam, namun dengan mulai dilaksanakannya program tersebut membuka peluang yang sangat luas bagi para santri untuk dapat mandiri dalam kehidupan di masa yang akan datang.

\section{KESIMPULAN}

Kesimpulan dari tulisan ini adalah Manajemen kurikulum merupakan satu kesatuan yang tidak bisa dipisahkan, dan manajemen kurikulum pesantren tentu tidak lepas dari fungsi-fungsi manajemen yang dikenal dengan istilah POAC yaitu planning, organizing, actuating, controling. Dimana keempat fungsi tersebut dikenal dengan istilah perencanaan, pengorganisasian, pelaksanaan, dan evaluasi. Pelaksanaan manajemen kurikulum pada prosesnya tentu membutuhkan sebuah perencanaan yang matang yang didukung oleh pengorganisasian yang tepat sehingga dapat menentukan skala prioritas, melaksanakan kurikulum dengan memanfaatkan sumber daya yang ada di pondok pesantren, dan tentunya dibarengi dengan evaluasi. Selanjutnya dalam upaya membentuk karakter mandiri santri dapat dilakukan dengan biasakan santri melakukan segala aktivitasnya sendiri tentunya dibarengi dengan pengawasan yang ketat dari pengasuh pondok pesantren. Karakter mandiri ini akan sangat dibutuhkan oleh para santri ketika santri sudah tidak berada di lingkungan pondok pesantren dan tidak lagi berada di lingkungan keluarga ketika mereka telah dewasa.

\section{REFERENCES}

[1] S. M. M. Wassalwa and H. F. Syarafah, "Manajemen Kurikulum Pesantren," at-Tahsin, vol. 1, no. 1 , pp. 1-15, 2021.

[2] R. Mubarok, "Manajemen Pembelajaran Santri Taman Pendidikan Al-Qur'an (TPA) Darus Sakinah Sangatta Utara,” Al-Rabwah, vol. XIV, no. 2, pp. 173-188, 2020.

[3] F. Siti, Manajemen Lembaga pendidikan, Cetakan I. Sleman Yogyakarta: Aswaja Pressindo, 2015.

[4] M. Huda, "Eksistensi Pesantren Dan Deradikalisasi Pendidikan Islam Di Indonesia," J. Kaji. Keislam. Dan Kemasyarakatan, vol. 3, no. 1, p. 91, 2018.

[5] S. Julaeha, "Problematika Kurikulum Dan Pembelajaran Pendidikan Karakter," J. Penelit. Pendidik. Islam., vol. 7, no. 2, pp. 157-182, 2019.

[6] N. Huda, "Manajemen Pengembangan Kurikulum," Al-Tanzim J. Manaj. Pendidik. Islam, vol. 1, no. 2, pp. 52-75, 2017.

[7] Y. Yuhasnil, "Manajemen Kurikulum dalam Upaya Peningkatan Mutu Pendidikan," Alignment J. Adm. Educ. Manag., vol. 3, no. 2, pp. 214-221, 2020. 
[8] M. Choiriah, "Manajemen kurikulum pendidikan anak usia dini (studi di TK Islam Miftahul Jannah Semarang).” UIN Walisongo, 2015.

[9] V. K. Sari, A. Akhwani, M. T. Hidayat, and D. W. Rahayu, "Implementasi Pendidikan Karakter Berbasis Nilai-nilai Antikorupsi Melalui Ekstrakurikuler dan Pembiasaan di Sekolah Dasar,” J. Basicedu, vol. 5, no. 4, pp. 2106-2115, 2021.

[10] A. Rohmah, "Implementasi Pendidikan Karakter di Pondok Pesantren Babul Khairat Purwosari Pasuruan.” Universitas Islam Negeri Maulana Malik Ibrahim, 2018.

[11] L. J. Moleong, Metode Penelitian Kualitatif. Bandung: PT. Remaja Rosdakarya, 2008.

[12] A. Suharsimi, Prosedur Penelitian: Suatu Pendekatan Praktik. Jakarta: Rineka Cipta, 2013.

[13] R. Mubarok, "Pelaksanaan Fungsi-Fungsi Manajemen Dalam Penigkatan Mutu Lembaga Pendidikan Islam,” Al-Rabwah, vol. 13, no. 01, pp. 27-44, 2019.

[14] T. W. Maduretno and L. Fajri, "The effect of optimization learning resource based on Planning, Organizing, Actuating, Controlling (POAC) on contextual learning to students' conceptual understanding of motion and force material," in Journal of Physics: Conference Series, 2019, vol. 1171, no. 1, p. 12012.

[15] M. Nur, C. Z. Harun, and S. Ibrahim, "Manajemen sekolah dalam meningkatkan mutu pendidikan pada sdn dayah guci kabupaten pidie," J. Adm. Pendidik. Progr. Pascasarj. Unsyiah, vol. 4, no. 1, 2016.

[16] I. Fathurrochman, "Implementasi Manajemen Kurikulum Dalam Upaya Meningkatkan Mutu Santri Pondok Pesantren Hidayatullah/Panti Asuhan Anak Soleh Curup,” TADBIR J. Stud. Manaj. Pendidik., vol. 1, no. 1, pp. 85-104, 2017.

[17] N. Indana and L. Nurvita, "Implementasi manajemen kurikulum pesantren di ponpes al urwatul wutsqo diwek jombang," Al-Idaroh J. Stud. Manaj. Pendidik. Islam, vol. 4, no. 1, pp. 29-51, 2020.

[18] D. Yatimah, "Manajemen Pendidikan Pesantren dalam Upaya Peningkatan Mutu Santri," elhikmah, no. 1, 2011.

[19] A. Ghozali, "Implementasi Pesan Dakwah Dalam Kitab Dalai'il Khairat bagi Santri Pondok Pesantren Al-Qaumaniah kauman jekulo kudus.” IAIN KUDUS, 2020.

[20] M. Imron, "Pendidikan Pondok Pesantren berbasis Agrobisnis dan Agroindustri: Studi di Pondok Pesantren Mukmin Mandiri, Waru, Sidoarjo.” UIN Sunan Ampel Surabaya, 2019.

[21] M. Qomar, “A. Latar Belakang Pesantren adalah lembaga pendidikan tradisional Islam untuk mempelajari, memahami, mendalami, menghayati, dan mengamalkan ajaran Islam dengan menekankan pentingnya moral keagamaan sebagai pedoman perilaku sehari-hari1. Kata 'tradisional.",

[22] R. H. Sa'diyyah, "Inovasi sistem pendidikan madrasah dalam mewujudkan madrasah yang berkualitas di MTSN Malang III Gondanglegi." Universitas Negeri Islam Maulana Malik Ibrahim, 2008.

[23] A. Mundiri and I. Zahra, "Corak Representasi Identitas Ustadz dalam Proses Transmisi Pendidikan Karakter di Pesantren,” J. Pendidik. Islam Indones., vol. 2, no. 1, pp. 21-35, 2017.

[24] A. Sulhan, "Manajemen Pendidikan Karakter Berbasis Budaya Santri dalam Mewujudkan Mutu Lulusan di MA Dakwah Islamiyah Putri Kediri Lombok Barat," J. Penelit. Keislam., vol. 14, no. 2, pp. 108-135, 2018.

[25] R. Mubarok, "Pengembangan Manajemen Sumber Daya Manusia di Lembaga Pendidikan Islam," Al-fahim J. Manaj. Pendidik. Islam, vol. 3, no. 2, pp. 131-146, 2021.

[26] L. Saajidah, "Fungsi-fungsi manajemen dalam pengelolaan kurikulum," J. Isema Islam. Educ. Manag., vol. 3, no. 2, pp. 201-208, 2018.

[27] A. Majir, Paradigma Baru Manajemen Pendidikan Abad 21. Deepublish, 2020.

[28] W. B. Sulfemi, "Manajemen Kurikulum di Sekolah,” 2019.

[29] I. Nasbi, "MANAJEMEN KURIKULUM: Sebuah Kajian Teoritis," Idaarah J. Manaj. Pendidik., vol. 1, no. 2, pp. 318-330, 2017, doi: 10.24252/idaarah.v1i2.4274. 
[30] D. S. Nahdi, "Self regulated learning sebagai karakter dalam pembelajaran matematika," $J$. THEOREMS (The Orig. Res. Math., vol. 2, no. 1, pp. 20-27, 2017.

[31] D. D. R. Nova and N. Widiastuti, "Pembentukan Karakter Mandiri Anak Melalui Kegiatan Naik Transportasi Umum,” Comm-Edu (Community Educ. Journal), vol. 2, no. 2, pp. 113-118, 2019.

[32] N. Qosim, “Aplikatif Manajemen Pendidikan dalam Pembentukan Karakter Santri,” At-Ta'lim J. Pendidik., vol. 6, no. 1, pp. 81-95, 2020.

[33] S. Asiyah, "Pendidikan Karakter Santri di Pondok Pesantren Ath-Thohiriyyah Karangsalam Kedungbanteng Purwokerto.” IAIN Purwokerto, 2015.

[34] K. Ramdhani and K. E. Waluyo, "Peranan Pendidikan Agama Islam Dalam Upaya Internalisasi Karakter Di Pondok Pesantren Nihayatul Amal Rawamerta Karawang,” J. Hadratul Madaniyah, vol. 6 , no. 2, pp. 1-15, 2019.

[35] A. Setiawan, "Bimbingan Anak di Panti Asuhan (Studi di Panti Asuhan Maulana Hasanuddin Cilegon, Banten).” Universitas Islam Negeri" Sultan Maulana Hasanuddin" Banten, 2018. 